Available online on 15.5.2018 at http://ujpr.org
Universal Journal of Pharmaceutical Research
An International Peer Reviewed Journal
Open access to Pharmaceutical research

\title{
EVALUATION OF THE IMMUNE RESPONSE TO POLIO VACCINE IN MALNOURISHED CHILDREN IN SANA'A CITY \\ Mogahid Y. Nassar ${ }^{1,2,} *$ (D) , Hassan A. Al-Shamahy ${ }^{3}$, , Ansam Mansor Mohammed AL-Barq ${ }^{3}$ \\ ${ }^{I}$ Department of Clinical Pathology, University of Science and Technology, Sana'a, Yemen. \\ ${ }^{2}$ Laboratory Department, University of Science and Technology Hospital, Sana'a, Yemen. \\ ${ }^{3}$ Department of Microbiology, Faculty of Medicine and Health Sciences, Sana'a University, Sana'a, Yemen.
}

\section{ABSTRACT}

Objective: This study was made to evaluate the immune response to polio virus vaccine among PEM children by measuring the level of circulating Immunoglobulin G (IgG) antibodies against polio virus (IgG-PV) after immunization with the primary series of POV, and determining the coverage rate of universal childhood vaccine for polio virus. A cross-sectional laboratory study was conducted in Department of Medical Microbiology and Clinical Immunology, Faculty of Medicine and Health Sciences, and AlSabeen University Hospital, Sana'a University.

Methods: A total of 279 PEM children were selected and investigated for universal childhood vaccination coverage rate for polio vaccine. Blood samples were collected from all, and then tested for levels of IgG-PV by ELISA method. For assessment IgG-PV levels more than 10 units $/ \mathrm{ml}$ were considered protected against polio virus infection.

Results: The coverage rate of polio virus vaccine for first year vaccine was $96.8 \%$; and $91.1 \%$ of vaccinated PEM children responded to the vaccine with mean level of $46.2 \mathrm{U} / \mathrm{ml}$. A statistically significant difference was observed with respect to seroprotective IgG-PV between males and females ( $85.7 \%$ and $94.1 \%$ respectively, $p=0.002)$; and older children $(>37$ months) (97.7\%).

Conclusion: Study conclude that a small proportion of malnourished vaccinated children with a normal immune status were not serologically immune to polio virus infection, and remain to be reconsidered for either revaccination or booster doses due to lack of or inadequate response. PEM group gave slightly reduced response to OPV hence there is need to give this group IPV (injectable polio vaccine) along with OPV and different micro-nutrition deficiencies like Zinc and iron.

Keywords: Children, malnutrition, PEM, polio vaccine, POV, Sana'a city, Yemen.

Article Info: Received 9 March 2018; Revised 20 April; Accepted 7 May, Available online 15 May 2018

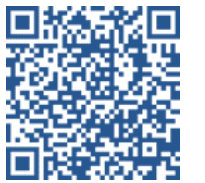

Cite this article-

Nassar MY, Al-Shamahy HA, AL-Barq AMM. Evaluation of the immune response to polio vaccine in malnourished children in Sana'a city. Universal Journal of Pharmaceutical Research 2018; 3(2): 27-31.

DOI: https://doi.org/10.22270/ujpr.v3i2.137

Address for Correspondence

Dr. Hassan A. Al-Shamahy, Department of Microbiology, Faculty of Medicine and Health Sciences, Sana'a University, Sana'a, Yemen. Tel.: +967-1-239551, E-mail: shmahe@yemen.net.ye

\section{INTRODUCTION}

Globally malnutrition is the most important cause for failure of all vaccination ${ }^{1,2}$. Consistent with Independent Monitoring Board of the Global Polio Eradication Initiative, Tenth Report 2014 on 28th of October 2014, globally 257 polio cases were reported in three polio endemic countries, of which 220 , wild polio cases were reported from Pakistan ${ }^{2,3,4}$. About 165 million children are universally, chronically malnourished. This preventable state has affected one in every four children. Malnutrition cause 2.3 million children deaths per year, an average of one death per every 15 seconds $^{5}$. According to WHO majority of expected malnourished children live in developing countries. Less than $30 \%$ of them are under the age of five years and half of them are suffering from PEM $^{1,2}$.
The report of MHP Yemen, and UNICEF shows the PEM is very high in Yemen among children $(50 \%)$ this Malnutrition might be one of the main difficulty for polio eradication among under five years old children in Yemen ${ }^{6}$. In its $41^{\text {st }}$ meeting in 1988 , World Health Assembly approved a declaration according to which "OPV is exclusively used worldwide for polio eradication for some reasons. It is cheaper than Intramuscular polio Vaccine (IPV) and can be easily orally administered"2. However, worldwide, the oral vaccine doesn't effectively develop immunity against polio, particularly in malnourished children ${ }^{7}$. Some data from WHO has also highlighted that malnutrition hinders the battle against polio because OPV produces four times less immunity in malnourished children as compared to well-nourished. Since $50 \%$ of under five 
children are malnourished in Yemen, it is very difficult to eradicate polio from Yemen ${ }^{6}$. Therefore, priority of current study should be focused on preventing malnutrition in this group of population.

This study was made to evaluate the immune response to polio virus vaccine among PEM children by measuring the level of circulating Immunoglobulin $G$ (IgG) antibodies against polio virus (IgG-PV) after immunization with the primary series of POV, and determining the coverage rate of universal childhood vaccine for polio virus.

\section{SUBJECTS AND METHODS Ethical Consideration}

Ethical clearance for the study was taken from the Faculty of Medicine and Health Sciences Research Review Committee. A written permission was also taken from the head of the pediatric department of the Al-Sabian Hospital, Sana'a city, Yemen. Informed Consent was taken from the parents and guardians of all selected children before the questionnaire was filled in and before the blood samples were collected.

\section{Survey procedure and Laboratory Analysis}

Demographic data and other relevant information of each participant were obtained through a questionnaire. Then, about $4 \mathrm{ml}$ of blood was aseptically drawn by venipuncture after swabbing the area of interest for sample collection with alcohol. The serum was then separated from the blood by allowing clotting and centrifuging. Finally, the serum samples were labeled and stored at $-20^{\circ} \mathrm{C}$ until processed. The polio $\mathrm{IgG}$ antibody ELISA test kit, manufactured and described by DEMEDITEC Diagnostic GmbH Germany, was used for the detection of specific $\operatorname{IgG}$ antibodies against polio in the serum of children with strict adherence to the manufacturer's instruction manual.

\section{Study setting}

The study was conducted at the pediatric department of the Al-Sabian Hospital, Sana'a city, Yemen. The Hospital was selected because it is the only teaching hospitals in Sana'a city provides health services to malnutrition children.

\section{Study Population}

Children between the age of 6 months to 59 months who attended the pediatric patient Department (PD) with PEM. These subjects of the study were taken from $17^{\text {th }}$ of March, 2017 to $17^{\text {th }}$ of September 2017 as the study population. It was ensured that they must have received first year oral polio vaccine doses and fulfill the eligibility criteria of study. A total of 279 blood samples were collected.

\section{Sample size}

The sample size was calculated by using sample size determination in health studies by WHO with $95 \%$ confidence interval and 5\% level of significance with acceptable margin of error equal to $6 \%$ with PEM population in Yemen at least equal to 500000 children. The proportions of antibodies production among malnourished subjects ("Evaluation of the response to vaccination against poliomyelitis and measles in malnourished children ${ }^{8}$ was $59.5 \%$ in malnutrition children. The sample size was calculated to be 257 subjects. In such a small sample size, the chance of type 1 and type 2 errors are increased. To reduce these errors in the study, we increased the sample size to 279 subjects.

\section{RESULTS}

The study included 270 malnourished children (126 males and 153 females). Most of children patients were in age group 13-24 months in which they count $36.9 \%$, followed by age group 3-12 months, in which the rate was $31.2 \%$ (Table 1 ).

Table 1: The age and sex distribution of malnourished children, whom tested for immune status against polio virus, Sana'a city, Yemen.

\begin{tabular}{ccccccc}
\hline \multirow{2}{*}{ Age groups } & \multicolumn{2}{c}{ Male } & \multicolumn{2}{c}{ Female } & \multicolumn{2}{c}{ Total } \\
\cline { 2 - 7 } & No & \% & No & \% & No & \% \\
\hline 6-12 months & 42 & 33.3 & 45 & 29.4 & 87 & 31.2 \\
13-24 months & 48 & 38.1 & 55 & 35.9 & 103 & 36.9 \\
25-36 months & 18 & 14.3 & 27 & 17.6 & 45 & 16.1 \\
37 months & 18 & 14.3 & 26 & 17 & 44 & 15.8 \\
Total & 126 & 45.2 & 153 & 54.8 & 279 & 100 \\
\hline
\end{tabular}

The non-protective of polio-antibodies $\mathrm{IgG}$ rate in children patients was $8.6 \%$, while the protective rate of polio-antibodies IgG in them was $91.4 \%$ (Table 2).

Table 2: The immune status of malnourished children against polio virus, Sana'a city, Yemen.

\begin{tabular}{|c|c|c|c|}
\hline Immune status & Number & Percentage & $P V$ \\
\hline $\begin{array}{l}\text { Non-protective } \\
\text { level of polio- } \\
\text { antibodies IgG } \\
(<9.9 \mathrm{IU} / \mathrm{ml})\end{array}$ & 24 & 8.6 & $<0.05$ \\
\hline $\begin{array}{l}\text { Protective level of } \\
\text { polio-antibodies } \\
\text { IgG } \\
(\geq 10 \mathrm{IU} / \mathrm{ml})\end{array}$ & 255 & 91.4 & \\
\hline Total & 279 & 100 & \\
\hline
\end{tabular}

There was $8.6 \%$ of malnourished children had 29.9IU/ml Polio-virus IgG antibodies (susceptibility to polio infection), $28.3 \%$ of them had $11-30 \mathrm{IU} / \mathrm{ml}$ (deprived protective level, and need urgent booster vaccine), $42.7 \%$ of malnourished children had 31$50 \mathrm{IU} / \mathrm{ml}$ (needy protective level which might faint in short time, and need booster vaccine), $10.4 \%$ of malnourished children had 51-70IU/ml Polio-virus IgG antibodies (good health protective level) and $10 \%$ of malnourished children had $\geq 71 \mathrm{IU} / \mathrm{ml}$ polio-virus $\mathrm{IgG}$ antibodies (fabulous protective level) (Table 3). The susceptibility rate to polio virus infection among males was $14.3 \%$, higher than that of females $3.9 \%$, with OR of susceptibility to poliovirus for male equal to 4.1 times than female $(p=0.002)$. As regard to the age, the susceptibility rates were increase in younger age groups (Table 4). Table 5 shows the associated odds ratio of susceptibility to polio virus infection with history of polio vaccine of malnourished children. There was high susceptibility rate to polio infection with children delivery in hospital $(9.1 \%)$, and history of first month illness $(9.5 \%)$ and in children had mixed feeding $(33.3 \%)$, but no statistical significance was observed (Table 6). 


\section{DISCUSSION}

Yemen introduced universal immunization against Polio virus infection for infants (POV) in early 70s of the last century, but feedback on the coverage rate of vaccinations and their efficacy in the community have been ignored for a long period. In addition, information on the prevalence and risk determinants of polio virus infection and on vaccination coverage rate and immune status against polio virus infection among children particularly malnourished children in Yemen has been inadequate or non-existent. Consequently, this study has been carried out to help our understanding of some of these questions. In addition, seroprevalence studies provide important data on act of immunization programs, susceptible groups and populations at-risk of future outbreaks. Identifying risk factors that affect seroconversion of the oral polio vaccine (OPV) will enable the polio eradication initiatives to increase seroprevalence. This study demonstrates the first hospital-based study aiming to determine the immune status of malnourished children in Sana'a city against polio virus. A total of 279 serum samples from malnourished children in Sana'a city were collected and analyzed in this study for polio-specific IgG antibodies, there was $91.4 \%$ of children had protective of polioantibodies IgG against polio virus infection, while $8.6 \%$ of tested children had non protective level of polio-antibodies IgG against polio virus infection, with other words they are susceptible and under risk of polio virus infections. The high seroprevalence of $91.1 \%$ recorded in this study among malnourished children in Sana'a city indicates children have effectively responded to the vaccine being used in the ongoing polio eradication initiative in spite of malnourished. These findings are similar with United States study in which it was reported that $90 \%$ of healthy school age children, adolescent and young adults had detectable antibodies to Poliovirus in spite of their nourished ${ }^{9}$. However, present seroprevalence of $91.1 \%$ is higher than the findings of Egypt by El-Sayed et al., ${ }^{10}$ (37.8\%) and Morocco by Yousuf et al., ${ }^{8}(21.4 \%)$, among malnourished children groups.

Table 3: The interpretations of the poliomyelitis virus IgG antibodies level among malnourished children, Sana'a city, Yemen.

\begin{tabular}{cccc}
\hline $\begin{array}{c}\text { Polio-virus IgG } \\
\text { antibodies } \\
\text { IU/ml }\end{array}$ & Number & Percentage & Interpretations' \\
\hline $2-9.9 \mathrm{IU} / \mathrm{ml}$ & 24 & 8.6 & Susceptible to polio infection \\
\hline $11-30 . \mathrm{IU} / \mathrm{ml}$ & 79 & 28.3 & $\begin{array}{c}\text { deprived protective level, need urgent } \\
\text { booster vaccine }\end{array}$ \\
\hline $31-50 \mathrm{IU} / \mathrm{ml}$ & 119 & 42.7 & $\begin{array}{c}\text { needy Protective level which might faint } \\
\text { in short time, need booster vaccine }\end{array}$ \\
\hline $51-70 \mathrm{IU} / \mathrm{ml}$ & 29 & 10.4 & in good health protective level \\
\hline$\geq 71 \mathrm{IU} / \mathrm{ml}$ & 28 & 10 & fabulous protective level \\
\hline
\end{tabular}

Table 4: The frequency and associated odds ratio of susceptibility to polio virus infection with different sexes and age groups of malnourished children in Sana'a city Yemen.

\begin{tabular}{|c|c|c|c|c|c|c|}
\hline \multirow[t]{2}{*}{ Characters } & \multicolumn{2}{|c|}{$\begin{array}{c}\text { Non-protective level } \\
\mathbf{N}=\mathbf{2 4}\end{array}$} & \multirow[t]{2}{*}{ OR } & \multirow[t]{2}{*}{ CI } & \multirow[t]{2}{*}{$\chi^{2}$} & \multirow[t]{2}{*}{$\mathbf{P V}$} \\
\hline & No & $\%$ & & & & \\
\hline Sex & & & & $1.6-10.6$ & 9.4 & 0.002 \\
\hline Male $n=126$ & 18 & 14.3 & 4.1 & & & \\
\hline Female $n=153$ & 6 & 3.9 & 0.24 & $0.1-0.6$ & 9.4 & 0.002 \\
\hline Age groups & & & & & & \\
\hline $6-12 \mathrm{~m} \mathrm{n}=87$ & 11 & 12.6 & 2 & $0.9-4.6$ & 2.6 & 0.1 \\
\hline $13-24 \mathrm{~m} \mathrm{n}=103$ & 9 & 8.7 & 1 & $0.4-2.4$ & 0.004 & 0.95 \\
\hline $25-36 \mathrm{~m} \mathrm{n}=45$ & 3 & 6.7 & 0.7 & $0.2-2.5$ & 0.25 & 0.61 \\
\hline$\geq 37 \mathrm{~m} \mathrm{n}=44$ & 1 & 2.3 & 0.21 & $0.02-1.6$ & 2.66 & 0.102 \\
\hline Total & 24 & 8.6 & - & - & - & - \\
\hline
\end{tabular}

The current study seroprevalence of protective IgG antibodies for polio virus was slightly higher $(94.1 \%)$ in females compared to males $(85.7 \%)$, this result is different from study by Iliyasu et al., ${ }^{11}$ in Nigeria, but similar to Donbraye et al., ${ }^{12}$. study in Nigeria where females had higher antibody titers for all the three serotypes. Also result of current study is similar to Baba et al., ${ }^{13}$ in India and to Chinese study by Wang et al., ${ }^{14}$. also. Sex differential non-specific effects of vaccines are common in developing countries with negative non-specific effects (NSE) of inactivated vaccines more common in girls than boys in some countries, but with no differences in high income countries $^{16,17}$. Though the general pattern is both negative and positive NSE are stronger in females ${ }^{18}$, a randomized controlled trial in Guinea-Bissau negated the hypothesis that mortality rates in boys would be lower if they had not received OPV ${ }^{19}$. The reasons why OPV uptake is slightly higher for females in current study area are unknown. Though factors such as age, gender and urban setting have no remedial solution from a public health perspective, this study indicates that response may be affected by factors that are not amenable to modification. This is important for the understanding of oral vaccine performance in lowincome countries. When we considered age groups, 
there was trend toward increased rate of positive protective levels of IgG antibodies against polio virus in the current study in which the higher seropositivity rate was in the older age group ( $\geq 37$ months age group) (97.7\%) and the lowest protective rate was $87.4 \%$ in 6-12 months age group (Table 4). This similar to findings in previous studies in Vellore district of Tamil Nadu - Sri Lanka in which lower rate of protective antibodies rate was found in children under one years of age ${ }^{20}$. This could be due to a more mature immune system or to receipt of OPV doses that are not recorded in the vaccination history taken for the child. When we study the associated odds ratio of susceptibility to polio virus infection with history of polio vaccine among malnourished children in Sana'a city Yemen, there was increased rate of susceptibility for polio virus in current study among children whom not had national camping booster polio vaccine in which the rate of susceptibility was $14.6 \%$, while the rate of susceptibility among children whom had national camping booster polio vaccine was $5.5 \%$ only (Table 5). Result of current study is similar to previously reported studies in which increasing the number of OPV doses received by children, decreasing the susceptibility rate for polio virus; and increase the polio-seroconversion rates among children ${ }^{8,11,21}$.

Table 5: The associated odds ratio of susceptibility to polio virus infection with history of polio vaccine of malnourished children in Sana'a city Yemen.

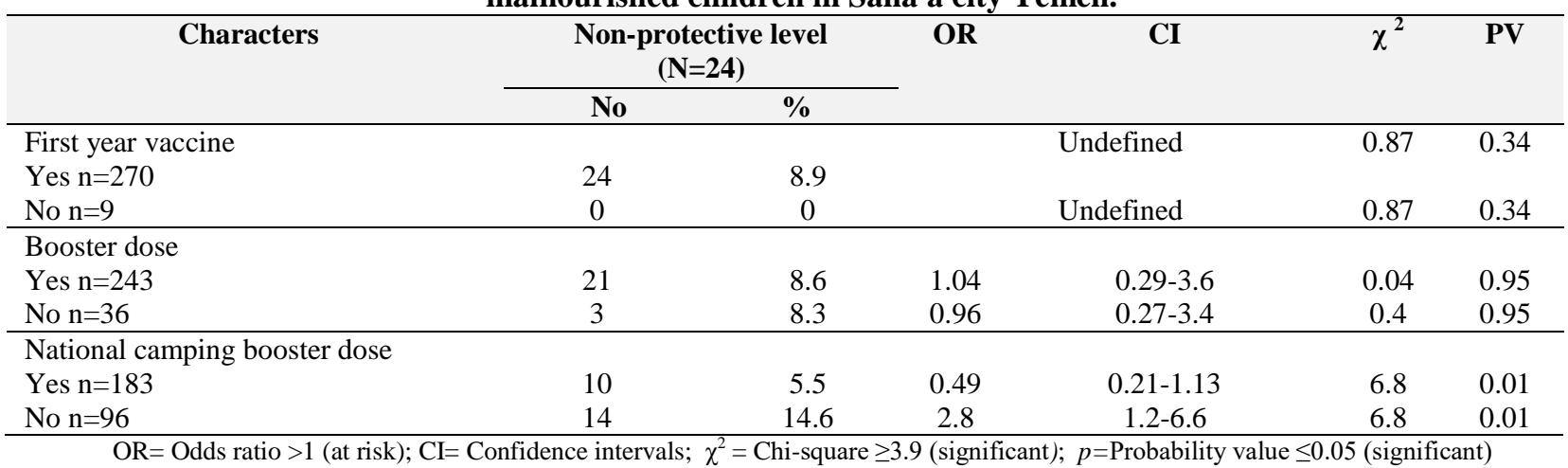

Table 6: The associated odds ratio of susceptibility to polio virus infection with site of delivery, history of illness during first month of life, and type of feeding of malnourished children in Sana'a city Yemen.

\begin{tabular}{|c|c|c|c|c|c|c|}
\hline \multirow[t]{2}{*}{ Characters } & \multicolumn{2}{|c|}{$\begin{array}{c}\text { Non-protective level } \\
\mathrm{N}=24\end{array}$} & \multirow[t]{2}{*}{ OR } & \multirow[t]{2}{*}{ CI } & \multirow[t]{2}{*}{$\chi^{2}$} & \multirow[t]{2}{*}{ PV } \\
\hline & No & $\%$ & & & & \\
\hline Site of delivery & & & 1.2 & $0.49-2.7$ & 0.12 & 0.72 \\
\hline Hospital $n=165$ & 15 & 9.1 & & & & \\
\hline House $n=114$ & 9 & 7.9 & 0.85 & $0.36-2.1$ & 0.12 & 0.72 \\
\hline \multicolumn{7}{|c|}{ History of first month illness } \\
\hline Yes $n=158$ & 15 & 9.5 & 1.4 & $0.6-3$ & 0.36 & 0.54 \\
\hline No $n=121$ & 9 & 7.4 & 0.7 & $0.3-1.8$ & 0.56 & 0.54 \\
\hline Type of feeding & & & 0.7 & $0.3-1.6$ & 0.18 & 0.40 \\
\hline Mother feeding $n=195$ & 15 & 7.7 & & & & \\
\hline Bottle feeding $n=75$ & 6 & 8 & 0.89 & $0.34-2.3$ & 0.05 & 0.82 \\
\hline Mixed n=9 & 3 & 33.3 & 5.9 & $1.4-25.4$ & 7.2 & 0.007 \\
\hline
\end{tabular}

$\mathrm{OR}=$ Odds ratio $>1$ (at risk); $\mathrm{CI}=$ Confidence intervals; $\chi^{2}=$ Chi-square $\geq 3.9$ (significant); $p=$ Probability value $\leq 0.05$ (significant)

\section{CONCLUSION}

We conclude that a small proportion of malnourished vaccinated children with a normal immune status were not serologically immune to polio virus infection, and remain to be reconsidered for either revaccination or booster doses due to lack of or inadequate response; more information, however, needs to be gathered first on the occurrence of clinical/subclinical poliomyelitis cases (morbidity and mortality) and the overall morbidity and mortality following polio vaccination. Also the rates of vaccine coverage for the routine immunization schedule of childhood vaccines were good.

\section{ACKNOWLEDGEMENTS}

Authors acknowledge the financial support of Sana'a University, Yemen.

\section{AUTHOR'S CONTRIBUTION}

The manuscript was carried out, written, and approved in collaboration with all authors.

\section{CONFLICT OF INTEREST}

No conflict of interest associated with this work.

\section{REFERENCES}

1. WHO. Polio vaccines: WHO position paper, March, 2016. Wkly Epidemiol Rec 2016; 91 (12): 145-168.

2. WHO. Poliomyelitis World Health Organization. Archived from the original on 18 April 2017.

3. Caidi H, Bennis IF, Mouan N, El Aouad R. Evaluation of the response to vaccination against poliomyelitis and measles in malnourished children in Morocco. East Mediterr Health J 2004; 10(4-5):474-481. PMID: 16335637

4. World Health Organization: National Surveillance Bulletin Pakistan. 2011

5. Jack Dean. "165 million children malnourished worldwide". World Socialist Web Site Published by the 
International Committee of the Fourth International (ICFI), 1 June; 2013.

6. MHP (Ministary of Health and Population, Sana', Yemen). National Surveillance Health report of Yemen 2017. https://doi.org/10.1177/0046958019847020

7. Sack DA, Qadri F, Svennerholm AM. Determinants of responses t oral vaccines in developing countries. Ann Nestlé (Engl Ed) 2008; 66(2):71-79. https://doi.org/10.1159/000129624

8. Yousuf A, Shah SA, Jaffery IA, et al. Seroprevalence rate of Poliovirus antibodies among the Healthy and Protein Energy Malnutrition children. Pak J Med Sci 2015; 31(2):403-407. https://doi.org/10.12669/pjms.312.5366

9. Kelley PW, Petruccelli BP, Stehr-Green P, Manson CJ. The susceptibility of young adult Americans to vaccinepreventable infections, natural sero-survey of US army recruits. J Am Med Assoc 1991; 266(19):2724-2729.

10. El-Sayed N, Al-Jorf S, Hennessey KA, Salama M, Watkins MA, Abdelwahab JA, et al. Survey of poliovirus antibodies during the final stage of polio eradication in Egypt. Vaccine 2007; 25(27):5062-5070. https://doi.org/10.1016/j.vaccine.2007.04.022

11. Iliyasu Z, Nwaze E, Verma H, Mustapha AO, Weldegebriel G, Gasasira A. Survey of poliovirus antibodies in Kano. Northern Nigeria. Vaccine 2014; 32(12):1414-1420. https://doi.org/10.1016/j.vaccine.2013.08.060

12. Donbraye E, Adewumi MO, Odaibo GN, Bakarey AS, Opaleye OO, Olaleye DO. Evaluation of immunity against poliovirus serotypes among children in Riverine areas of Delta State, Nigeria. African J Clin Exp Microbiol 2011; 12(2):72-75. https://doi.org/10.4314/ajcem.v12i2.64321

13. Baba MM, Haruna BA, Ogunmola O, Ambe JP, Shidali NN, Oderinde B. A survey for neutralizing antibodies to the three types of poliovirus among children in Maiduguri. Nigeria $\mathbf{J}$ Med Virol 2012; 84(4):691-696. https://doi.org/10.1002/jmv.23228

14. Wang $H$, Cui $H$, Ding $Z$, Ba $P$, Zhu $S$, Wen $N$. Seroprevalence of anti-polio antibodies among children $<15$ years of age in border provinces in China. Clin Vaccine Immunol 2013; 20(7):1070-1075. https://doi.org/10.1128/CVI.00092-13

15. Aaby P, Jensen H, Gomes J, Fernandes M, Lisse IM. The introduction of diphtheria-tetanus-pertussis vaccine and child mortality in rural Guinea-Bissau: an observational study. Int J Epidemiol 2004; 33(2):374-380. https://doi.org/10.1016/j.ebiom.2017.01.041

16. Aaby P, Jensen H, Walraven G. Age-specific changes in the female-male mortality ratio related to the pattern of vaccinations: an observational study from rural Gambia. Vaccine 2006; 24(22):4701-4708 https://doi.org/10.1016/j.vaccine.2006.03.038

17. Schurink-Van't, Klooster TM, Knol MJ, De Melker HE, Van der Sande MA. Gender-specific mortality in DTP-IPV- and $\mathrm{MMR}^{+}$-Men C-eligible age groups to determine possible sex-differential effects of vaccination: an observational study. BMC Infect Dis 2015; 15:148. https://doi.org/10.1186/s12879-015-0898-8

18. Flanagan KL, Van Crevel R, Curtis N, Shann F, Levy O, Optimmunize N. Heterologous ("nonspecific") and sexdifferential effects of vaccines: epidemiology, clinical trials, and emerging immunologic mechanisms. Clin Infect Dis 2013; 57(2):283-289. https://doi.org/10.1093/cid/cit209

19. Lund N, Andersen A, Hansen AS, Jepsen FS, Barbosa A, Biering-Sorensen $\mathrm{S}$. The effect of oral polio vaccine at birth on infant mortality: a randomized trial. Clin Infect Dis 2015; 61(10):1504-1511. https://doi.org/10.1093/cid/civ617

20. Gamage D, Palihawadana P, Mach O, Weldon WC, Oberste SM, Sutter RW. Achieving high seroprevalence against polioviruses in Sri Lanka-Results from a serological survey, 2014. J Epidemiol Glob Health 2015; 5(4 Suppl. 1):S67S71. https://doi.org/10.1016/j.jegh.2015.06.004

21. Staat MA, Stadler LP, Donauer S, Trehan I, Rice M Salisbury S. Serologic testing to verify the immune status of internationally adopted children against vaccine preventable diseases. Vaccine 2010; 28(50):7947-7955. https://doi.org/10.1016/j.vaccine.2010.09.069 